\title{
HET SPAAR- EN \\ KREDIETPROGRAMMA VAN \\ VREDESEILANDEN / RAFIA IN \\ NOORD-TOGO: EEN KRITISCHE \\ EVALUATIE ${ }^{1}$
}

\section{Patrick VAN DAMME \& Inge HATSE}

\author{
Patrick Van Damme \\ Afdeling Tropische en Subtropische Landbouw en Etnobotanie \\ Coupure Links 653 \\ 9000 Gent \\ Inge Hatse \\ p/a Vredeseilanden v.z.w. \\ Ruelensvest 127 \\ 3000 Leuven
}

\section{SUMMARY : THE SAVINGS AND CREDIT PROGRAM OF VREDESEILANDEN (ISLANDS OF PEACE) / RAFIA IN NORTHERN-TOGO : A CRITICAL EVALUATION}

Northern Togo has never been over-assisted as some of the other dry and poor areas of West Africa have been. It has never been a priority of national or international development organisations. As a consequence, the area has intermittent food security problems. Islands of Peace (Vredeseilanden), a Flemish NGO for development cooperation, however, has initiated a (successful) savings and credit scheme based on local surpluses which now allows local populations to invest and consolidate their (food security) situation.

\footnotetext{
${ }^{1}$ Deze tekst geeft de situatie weer medio 1994.
} 


\section{KAART 1}

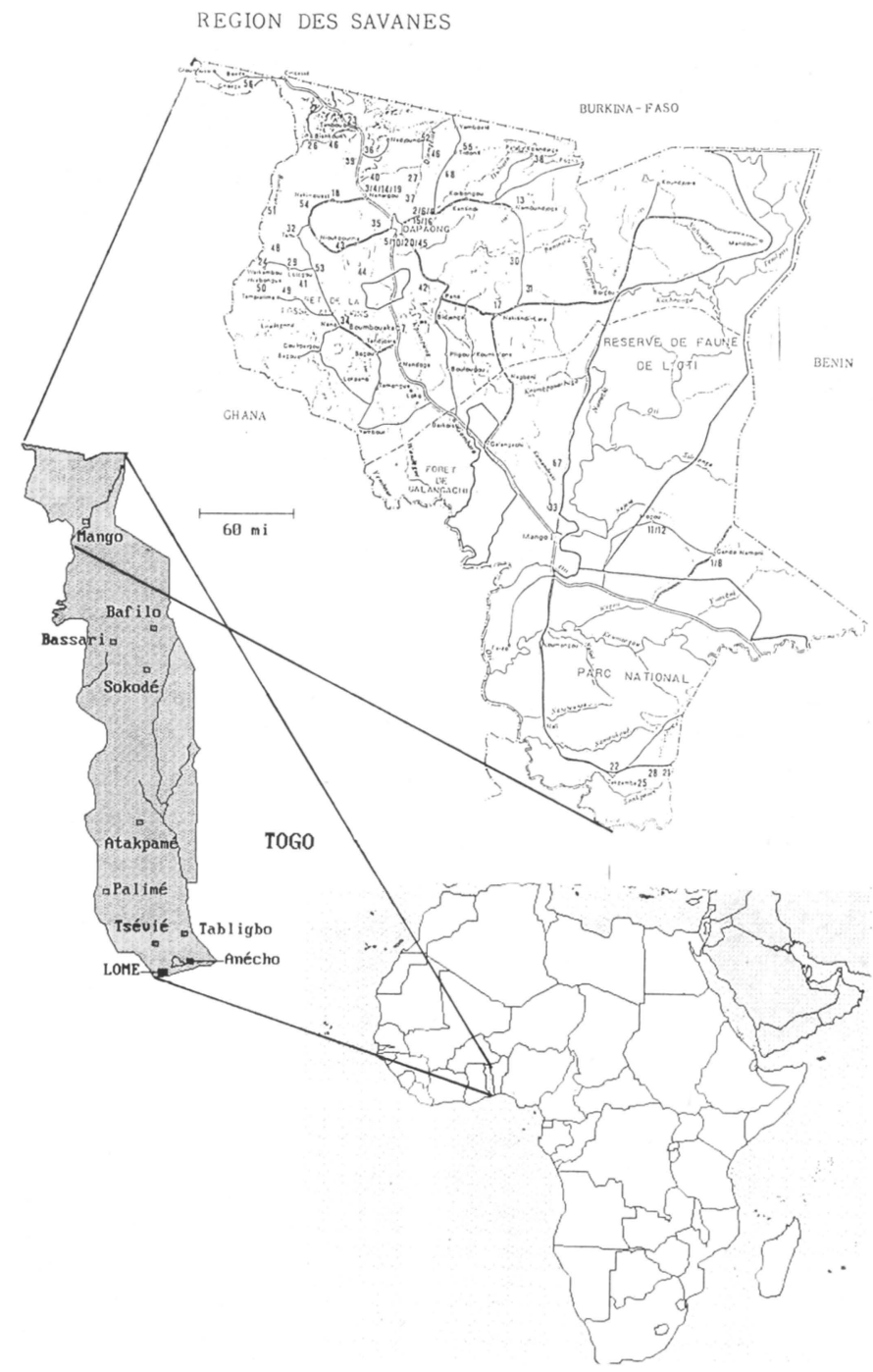

Projectzone van het project van $V E / R A F I A$, in Noord-Togo 
KEYWORDS : tontines, informal savings, rural credit, sustained development

\section{INLEIDING}

De v.z.w. Vredeseilanden, een Vlaamse NGO voor ontwikkelingssamenwerking, is al tien jaar actief in de Région des Savanes, Noord-Togo. Naast begeleiding van technische ontwikkelingsinterventies, intervenieert de organisatie ook op het vlak van

spaar- en kredietactiviteiten. Deze laatsten worden immers als 'motor' voor ontwikkeling beschouwd.

In wat volgt worden de aanpak en achtergrondfilosofie besproken en kritisch geanalyseerd, niet zonder eerst de interventiezone te hebben voorgesteld. Voor andere en meer uitgebreide informatie over de organisatie en haar doelstellingen, zij verwezen naar de literatuurlijst op het einde van het artikel.

\section{ALGEMENE BESCHOUWINGEN OVER DE REGION DES SAVANES}

\subsection{Geografisch (kaart 1)}

De Région des Savanes, met als hoofdplaats Dapaong, is de meest noordelijk gelegen provincie van Togo. Ze kent op veel gebieden een achterstand tegenover de rest van het land. Het transport naar de hoofdstad vormt een probleem gezien de grote afstand (ongeveer $500 \mathrm{~km}$ ), en de chronisch slechte staat van de (enige) asfaltweg.

Een derde van de oppervlakte was tot 1993 voorbehouden aan natuurreservaten. Hierdoor werd doorgaans vruchtbare grond aan landbouw onttrokken. $\mathrm{Na}$ de recente politieke strubbelingen werden deze gebieden ingenomen door grote groepen landbouwers die er nu permanent aan landbouw doen. De streek kent een lang en streng droog seizoen van oktober tot mei. Tijdens deze periode is 
landbouwactiviteit nagenoeg onmogelijk, terwijl ook de veeteeltsector lijdt onder het gebrek aan water en, afgeleid, goed voeder. De afwisseling tussen een intense droge periode en een aantal hevige regens gedurende het regenseizoen, heeft ertoe geleid dat heel veel bodems in de regio nagenoeg totaal onvruchtbaar geworden zijn (bodemerosie en -degradatie).

\subsection{Sociologisch}

Verschillende etnieën bevolken de streek. De voornaamste groep zijn de Moba, terwijl ook Gourma, Peulh en Mossi in de streek wonen. Vooral het noordwesten heeft een hoge bevolkingsdichtheid. De hele streek heeft te kampen met een tekort aan medische infrastructuur en veilig drinkwater, terwijl ook de inkomens en scholings- en alfabetisatiegraad laag zijn. Veel kinderen zijn kritisch ondervoed. De kindersterfte bedroeg $10 \%$ in 1986. De levensverwachting is er 10 jaar lager (cijfers van 1986) dan gemiddeld in Togo. Ongeveer $96 \%$ van de bevolking werkt er in de overlevingslandbouw.

\subsection{Landbouw}

Omwille van de grote bevolkingsdruk wordt de grond intens bewerkt (meer dan $80 \%$ van de gronden in Dapaong en verder noordwaarts zijn permanent in gebruik) zonder dat de export (via de oogst) en het verlies (door uitspoeling) aan mineralen in de bodem gecompenseerd worden door bemesting (noch organisch, noch anorganisch). Hierdoor raakt de bodem meer en meer gedegradeerd en is herbebossing van levensbelang. Het niveau van de waterlopen schommelt sterk: op een enkele uitzondering na bevatten zij enkel water gedurende het regenseizoen, waardoor irrigatie uit oppervlaktewater onmogelijk is.

De voedselgewassen die er verbouwd worden, zijn vooral: gierst (Pennisetum americanum), sorghum (Sorghum bicolor) en bonen (Vigna unguiculata). In het zuidoosten van de streek worden ook rijst (Oryza spp.), maïs (Zea mays) en yam (Dioscorea-soorten) geteeld (tabel 1). Sinds het midden van de jaren ' 80 worden zij echter meer en meer verdrongen door de katoen- (Gossypium spp.) en aardnotenteelt (Arachis hypogaea). Het noordwesten is zowel regionaal als nationaal een graanschuur (gierst, Pennisetum americanum). Ook hier gaat zoals overal elders in de derde wereld echter gemiddeld 10 tot $20 \%$ van de oogst verloren door slecht voorraadbeheer. 
Tabel 1: VOORZIENE PRODUCTIE (in ton) PER STREEK VAN VOEDSELGEWASSEN IN HET SEIZOEN ' 92 -'93

\begin{tabular}{|l||c|c|c|c|c|c|}
\hline STREEK & $\begin{array}{l}\text { MARITI- } \\
\text { ME }\end{array}$ & $\begin{array}{l}\text { PLA- } \\
\text { TEAU }\end{array}$ & $\begin{array}{l}\text { CEN- } \\
\text { TRALE }\end{array}$ & KARA & $\begin{array}{l}\text { SAVA- } \\
\text { NES }\end{array}$ & TOGO \\
\hline GRANEN & 56898 & 132227 & $\mathbf{7 5 5 1 6}$ & $\mathbf{4 4 7 5 3}$ & 146736 & $\mathbf{4 5 6 1 3 1}$ \\
\hline $\begin{array}{l}\text { maïs } \\
\text { sorghum / }\end{array}$ & 56898 & 101426 & 40417 & 20277 & 20428 & 239447 \\
gierst & - & 26219 & 22770 & 21364 & 120456 & 190809 \\
rijst & - & 4582 & 12329 & 3112 & 5852 & 25875 \\
tarwe & - & - & - & - & - & - \\
\hline KNOLLEN & 294287 & 216933 & 225900 & 131781 & 10697 & $\mathbf{8 8 4} 498$ \\
\hline yam & 53052 & 113665 & 133336 & 77204 & 10697 & 392954 \\
maniok & 234725 & 98125 & 92417 & 54577 & - & 479844 \\
andere & 6510 & 5143 & 47 & - & - & 11700 \\
\hline PEULEN & 4643 & 2806 & 10782 & 8353 & 19411 & 45995 \\
\hline bonen & 3187 & 1500 & 4181 & 2360 & 11107 & 22335 \\
aardnoten & 1426 & 1306 & 6430 & 5038 & 7766 & 21966 \\
andere & 30 & - & 171 & 955 & 538 & 1694 \\
\hline
\end{tabular}


De veeteelt heeft zowel regionaal als nationaal belang, maar blijft traditioneel omwille van het tekort aan financiële middelen, grond, drinkwaterputten en een gebrekkige diergeneeskundige infrastructuur. De veestapel kan dus maar traag aangroeien. Twee derde van het geproduceerde vlees wordt verkocht op de plaatselijke markten van Dapaong en Mango. Met een groter accent op de teelt van geiten en kippen zou zelfvoorziening voor vlees mogelijk zijn. Koeien worden meer als statussymbool gezien.

\subsection{Economisch}

De voornaamste economische activiteit is de landbouw. Er komt slechts zeer weinig verwerkende nijverheid voor met uitzondering van artisanaal textiel en leerlooierij in de stedelijke centra. Mijnbouw is er niet. Dapaong en Mango zijn belangrijke handelscentra. Het zijn vooral verzamel- en doorvoercentra voor landbouwproducten. De import in de Région des Savanes is zeer beperkt.

\section{Het bankwezen}

Een groot deel van de 'West-Afrikaanse regio (Benin, Burkina Faso, Ivoorkust, Mali, Niger, Senegal en Togo) behoort tot de UMOA (Union Monétaire OuestAfricaine). De centrale bank van de UMOA, de BCEAO (Banque Centrale des Etats de l'Afrique de l'Ouest) is gevestigd in Dakar.

De gemeenschappelijke instelling voor de financiering van de ontwikkelingsinitiatieven van de lidstaten van de UMOA is de BOAD (Banque Ouest-Africaine de Développement), die jammer genoeg volledig gericht is op kredietverlening in het groot (ze geeft bv. leningen aan staten), en alleen tussenkomt voor investeringen in de privé-sector (industrie, transport, landbouw, visvangst, toerisme, energie,...) voor doorgaans (al) grote en kapitaalkrachtige bedrijven die goederen en diensten produceren of verdelen met veel winst. De kleinschalige verwerking en handel krijgen geen kredieten verstrekt.

Naast de structuren van de UMOA zijn er de privé-banken zoals de UTB (Union Togolaise de Banque), BTD, BTCI, BIAO,... die zich vooral op de stedelijke markten bewegen, en doorgaans weinig risico's nemen wat hun investeringsbeleid betreft. 
Vroeger bestond er een officiële, meer sociaalgerichte rurale bank, die oog had voor de kleine producent, namelijk de CNCA (Caisse Nationale de Crédit Agricole). Maar door welig tierende corruptiepraktijken onder de ambtenaren en slecht beheer (veronachtzamen van terugbetalingen, gebrekkige kapitaalsbasis,...) is deze failliet gegaan in 1990. Op het platteland is de bankservice globaal genomen erg onderontwikkeld en in de meeste gevallen zelfs onbestaande.

De BCEAO verleent over heel de regio kredieten aan dezelfde intrestvoeten, die onder impuls van het derde structureel aanpassingsprogramma (SAP, '87-'89) verhoogd werden om meer spaarkapitaal aan te trekken.

Op een gewone spaarrekening bedraagt de rente 6,5 tot $7,5 \%$, afhankelijk van het gespaarde bedrag. Hier zit echter wel een addertje onder het gras: je moet namelijk minstens $50.000 \mathrm{fCFA}^{2}$ sparen vóór je deze intrest krijgt, en deze som moet heel de tijd intrestloos ter beschikking van de bank blijven! Een kleine boer, die doorgaans amper (in het beste geval) 5 à 10.000 fCFA kan opzij leggen, kan dus nooit een rekening openen. Daarenboven profiteren de banken op deze manier optimaal van enorme sommen geld zonder dat ze er zelf kosten op moeten betalen.

De officiële kredietrentes liggen tussen 15 en $20 \%$.

Met de devaluatie van de fCFA zijn vele privé-banken in de problemen gekomen: vroeger kregen zij een vaste rente op geld dat zij bij de BCEAO vastzetten. Dit systeem is nu afgeschaft, en nu wordt duidelijk dat vele banken geen goede bankiers waren, maar gewoon hun geld ergens veilig deponeerden. Er zijn geruchten dat vele banken op de korte termijn failliet zouden kunnen gaan.

\section{EPARGNE ET CREDIT VILLAGEOIS, EEN PROJECT VAN VE/RAFIA}

\subsection{Ontstaansgeschiedenis}

Epargne et crédit villageois is een spaar- en kredietprogramma, opgestart vanuit een groot aantal informele groepen, die sinds 1986 begeleid worden door

${ }^{2} 16 \mathrm{fCFA}=1 \mathrm{BEF}$ 
Vredeseilanden (VE) in Noord-Togo in de zone die boven Dapaong gelegen is (zie kaart 1). Ondertussen zijn er heel wat nieuwe groepen ontstaan en is de begeleidende functie overgenomen door de lokale, Togolese NGO RAFIA, opgericht onder impuls van VE. VE blijft zich wel nog engageren via een bijdragefonds gedurende 4 jaar (1992-1996), dat gecofinancierd wordt door de Belgische Ontwikkelingsadministratie (ABOS) en de EU.

Het spaar- en kredietprogramma ligt in de lijn van een globaal ontwikkelingsproject dat door Vredeseilanden werd opgezet, en vormt een belangrijk element naar de rest van de activiteiten van het project toe. Integratie met de andere luiken van het project (bescherming en bewaring van voedselvoorraden, erosiebestrijding en dambeheer, groententuinen, ondersteuning van de informele sector,...), dat een globale verbetering van de levensvoorwaarden van de bevolking nastreeft, is altijd al een uitgangspunt geweest. Meer nog: doordat het spaar- en kredietluik een wezenlijk onderdeel uitmaakt van het globale Vredeseilandenprogramma versterkt het de werking van de andere deelprojecten, terwijl de lokale bevolking zelf meer gestimuleerd wordt om er aan deel te nemen omdat de spaar- en kredietactiviteiten een direct doel krijgen, en toelaten de eigen socio-economische situatie te verbeteren.

\subsection{Socio-economische context}

Tijdens een normaal jaar kan de voedselproductie in de regio meer dan voldoende in het levensonderhoud van de lokale bevolking voorzien. Toch treedt er een jaarlijks terugkerende voedselschaarste op gedurende het droogseizoen, waardoor de graanprijs op de markt vanaf juli verdubbelt en er in deze overgangsperiode (soudure of tiding over period) dikwijls ondervoeding in de dorpen voorkomt.

Enkele oorzaken van dit fenomeen zijn terug te voeren tot grote verliezen (10 tot $20 \%$ ) door onvoldoende opslag- en bewaarfaciliteiten en een groot verbruik na de oogst in het kader van feesten en, in meer algemene termen, socio-culturele activiteiten. De boeren zien zich dan ook dikwijls genoodzaakt om tijdens de overgangsperiode voedsel bij te kopen en zich hiervoor dikwijls in de schuld te steken. In vele gevallen zijn zij dan niet in staat om hun productiefactoren ${ }^{3}$ (meststoffen, pesticiden,...) zelf te financieren en moeten ze tegen woekerintresten lenen bij groothandelaars (vb. $330 \%$ per jaar voor zaaizaad).

\footnotetext{
${ }^{3}$ De term productiefactoren wordt hier gebruikt voor alles wat "roerende" factoren zijn die de productie mogelijk maken. Een andere, veel gebruikte term is inputs.
} 
In de streek van het project voorziet de overheid weinig landbouwomkadering. Ongeveer $80 \%$ van de groepen die nu deelnemen aan het spaar- en kredietprogramma van Vredeseilanden, had voordien te maken met de landbouwvoorlichters van de DRDR (Direction Régionale du Développement Rural; het ministerie van plattelandsontwikkeling en landbouw), van de paraopenbare onderneming SOTOCO die zorgt voor begeleiding van teelt en vermarkting van katoen, en van de diensten van vooral internationale NGO's (een dertigtal in '86) die de boeren ondersteunen.

Sinds het failliet van de CNCA in 1990 ontstonden wel verschillende alternatieve kredietsystemen waaronder AVE (Association Village Entreprise) en CAP (zie verder) die voor een deel tegemoet kwamen/komen aan de kredietbehoeften van het platteland.

De organisatievorm die eigenlijk geroepen was om op lokaal vlak de functie van de CNCA over te nemen, met name de COOPEC (Coopération d'Epargne et de Crédit; aparte spaar- en kredietcoöperatieven, gegroepeerd in een koepel, FUCEC genaamd Fédération des Unions de Coopération d'Epargne et de Crédit), waarvan er in Togo zo'n 200 bestaan (sommige grote bedrijven hebben zelfs een eigen COOPEC), profileerde zich echter meer en meer als een organisatie die haar activiteiten beperkte tot de stedelijke zones en betekende dus niet veel voor de rurale boer. Tegenwoordig heeft de FUCEC echter toch plannen om ook het rurale gebied te 'ontsluiten'. SOTOCO was vroeger wel al actief op kredietgebied en had ook acties met groepsverantwoordelijken op dorpsniveau op het vlak van voedselgewassen, en verleende inputs en krediet.

De overheid is zich bewust van de noodzaak om een degelijke kredietpolitiek uit te bouwen maar verder dan tot wat voorbereidend denkwerk is zij voorlopig nog niet gekomen.

\subsection{Doel}

Het doel van het spaar- en kredietproject van VE is de boeren - zowel mannen als vrouwen - (in aparte groepen) aan te zetten tot een collectieve mobilisatie en beheer van door hen gespaarde hoeveelheden landbouwproducten (in natura) en/of geld. Deze gespaarde middelen worden door de mannen op een productieve manier geïnvesteerd (dit wil zeggen vooral in noodzakelijke landbouwinputs en machines voor de verwerking van landbouwproducten), door de vrouwen worden ze veelal aangewend als financiële hefboom om handelsactiviteiten te financieren. 
Het basisprincipe van de ondersteunde spaar- en kredietactiviteiten is dat individuele landbouwers zich organiseren in groepen en het gespaarde samenbrengen onder een gemeenschappelijk beheer. Hierdoor zal het individu minder gemakkelijk de neiging vertonen om het gespaarde al of niet onder druk van derden voor nutteloze/minder verantwoorde doeleinden te gebruiken. De groepssolidariteit maakt bovendien dat de middelen die vrijkomen door verkoop van de gespaarde hoeveelheden of dat het gespaarde geld zelf, optimaal gebruikt kunnen worden, na overleg en gemeenschappelijk akkoord.

Van bij hun ontstaan werken de groepen samen rond een aantal thema's die het wezenlijke van de spaaractie uitmaken of ze vergemakkelijken, bv. samen een graanschuur oprichten of een voorraad gierst aanleggen en aanhouden tot de overgangsperiode.

Op een vastgestelde datum (wanneer de eigen gierstvoorraad van het modale groepslid ongeveer opgebruikt is), wordt een bepaalde hoeveelheid graan ontleend aan de gemeenschappelijk beheerde graanvoorraad door hen die erom vragen. De terugbetaling gebeurt uit de volgende oogst met een intrestvoet van $50 \%$ (looptijd lening: 4 à 6 maand). Dit lijkt veel maar is toch veel lager dan bij lening bij een commerciële handelaar.

Zo vermeerdert natuurlijk de voorraad bij volledige terugbetaling, totdat op een dag de volledige behoeften verzekerd zijn en er gestockeerd kan worden voor de verkoop. Een deel van de opbrengst hiervan kan dan gespaard worden onder de vorm van geld, wat de groep toelaat kredieten in speciën te verstrekken aan zijn leden, die vooral bedoeld zijn om acute uitgaven te dekken. In een later stadium moet het bovendien mogelijk zijn om met dit geld meer formele vormen van krediet (op de vrije markt) aan te gaan. Dit laatste stadium werd bereikt in de periode 1994/95.

\subsection{Evolutie}

Er is een duidelijke vooruitgang merkbaar in het aantal spaargroepen (kwantiteit) en inzake spaarplanning, -organisatie en -beheer (kwaliteit) binnen elke groep.

Het project startte initieel in de centrale regio van de projectzone, maar nam al snel uitbreiding naar het oosten toe. De uitbreiding naar het westen vatte aan in 1992. Tegen het einde van dat jaar was $40 \%$ van de boeren bereikt tegenover 27 $\%$ in ' 90 . Tegen eind '94 hoopt men dat een groot deel van de bevolking van de zone inderdaad actief betrokken is bij het spaar- en/of kredietluik van het project. 
Tabel 2: SAMENSTELLING EN SPAARVOLUME (IN NATURA EN GELD) VAN DE MANNENSPAARGROEPEN IN DE REGION DES SAVANES

\begin{tabular}{|l|r|r|r|r|r|r|r||}
\hline & $866 / 87$ & $187 / 88$ & $\mathbf{8 8 / 8 9}$ & $\mathbf{8 9 / 9 0}$ & $\mathbf{9 0 / 9 1}$ & $\mathbf{9 1 / 9 2}$ & $\mathbf{9 2 / 9 3}$ \\
\hline Aantal groepen & 8 & 22 & 28 & 30 & 54 & 78 & 96 \\
Aantal leden & 96 & 164 & 316 & 360 & 864 & 1120 & 1497 \\
\hline Gespaarde hoeveelheid \\
\hline in natura (ton) & 3,21 & 8,04 & 9,97 & 22,52 & 27,00 & 27,50 & 90,18 \\
in geld & $*$ & $*$ & $*$ & 336 & 384 & 812 & 510 \\
$(\mathbf{1 0 0 0}$ fCFA) & & & & & & & \\
\hline
\end{tabular}

Tabel 3: SAMENSTELLING EN SPAARVOLUME (IN NATURA EN GELD) VAN DE VROUWENSPAARGROEPEN IN DE REGION DES SAVANES

\begin{tabular}{|c|c|c|c|c|c|c|c|}
\hline & '86/87 & '87/88 & '88/89 & '89/90 & '90/91 & '91/92 & '92/93 \\
\hline Aantal groepen & * & 35 & 35 & 48 & 63 & 89 & 120 \\
\hline Aantal leden & * & 832 & 940 & 1258 & 1638 & 2050 & 2784 \\
\hline \multicolumn{8}{|c|}{ Gespaarde hoeveelheid } \\
\hline in natura (ton) & $*$ & 5,45 & 6,93 & 16,26 & 20 & 27 & 67,92 \\
\hline $\begin{array}{l}\text { geld (1000 } \\
\text { fCFA) }\end{array}$ & $*$ & * & * & $\left({ }^{*}\right)$ & $\left({ }^{*}\right)$ & 737 & 635 \\
\hline
\end{tabular}


Tabel 4: OVERZICHT VAN ENKELE KENMERKEN VAN CAP

\begin{tabular}{|l||c|c|c|}
\hline & 1991 & 1992 & 1993 \\
\hline \hline Aantal lidgroepen & 64 & 117 & 134 \\
\% van het totaal aantal groepen & 54 & 70 & 62 \\
Totaal toegekende kredietsom & 4000000 & 8156000 & 10380000 \\
(fCFA) & & & \\
Mannengroepen met krediet & 20 & 32 & 37 \\
$\quad$ aantal personen & 240 & 512 & $640^{*}$ \\
Vrouwengroepen met krediet & 20 & 39 & 43 \\
$\quad$ aantal personen & 520 & 975 & 1325 \\
Terugbetaalde som & 4400000 & 9092600 & 4578790 \\
\hline
\end{tabular}

* : gegevens zijn onvolledig

$\left(^{*}\right) \quad$ : met het spaargeld werd gierst aangekocht 
In alle groepen zijn vrouwen veel actiever dan mannen: na hun huwelijk komen zij meestal in een voor hen 'vreemd' dorp terecht (exogamie), en voelen zij dan ook een sterke behoefte om zich daar samen beter te organiseren.

In het begin voorzagen de spaargroepen in leningen in natura aan zeer variabele rentevoeten (tot $200 \%$ voor leden, en voor niet-leden zelfs tot $600 \%$ ).

Omwille van het belang van de graanstock, zowel strategisch als naar volume, begon men in 1990 met de constructie van verbeterde graanschuren. Het doel was er minstens één per dorp te hebben.

Tabellen 2 en 3 geven een overzicht van de evolutie van de samenstelling van de spaargroepen en het gespaarde volume gedurende de eerste jaren van het programma. De 27,5 ton die de 70 mannengroepen in 1992 gespaard hebben, was ongeveer even groot als die van het jaar voordien omwille van de slechte oogst. Het effect van een goede of slechte oogst weegt blijkbaar minder door bij de vrouwengroepen ( 27 ton in '92 t.o.v. 20 ton in '90). Dit kan verklaard worden door het feit dat zij niet betrokken worden bij het beheer van de oogsten van de familievelden. Wat zij sparen komt van wat zij krijgen van hun echtgenoot, wat zij van hun kleine persoonlijke veldjes oogsten, wat zij op gemeenschappelijke velden oogsten of van wat zij kopen op de markt. Bovendien wordt er ook dikwijls gespaard onder de vorm van rijst die in principe minder te lijden heeft onder droogte, of andere invloeden die de rendementen negatief kunnen beïnvloeden.

Wat de mannen sparen, kan gezien worden als een extraatje. Voor de vrouw is het veeleer een noodzaak. Zij beteelt meestal de kleinste veldjes op de slechtste gronden, en ze heeft maar heel weinig tijd over om voor de eigen teelten te zorgen, aangezien zij eerst een hele resem andere taken moet vervullen zoals werken op de familievelden, zorgen voor de kinderen, brandhout, bereiding van de maaltijden, ...

De vrouw is dan ook het meest geïnteresseerd in de spaaractiviteiten, vermits zij heel goed begrijpt dat ze op basis hiervan op termijn kredieten kan krijgen die ze kan gebruiken om voedselzekerheid te garanderen voor haar gezin, en om aan kleine 'commerce' te doen. Hierdoor kan ze wat extra verdienen, en financiële onafhankelijkheid verwerven.

In 1991 telden de verschillende groepen in totaal zo'n 3.000 leden (waarvan 2.000 vrouwen) en met de oogst van '91/'92 haalden zij een totale gespaarde hoeveelheid van 50 à 60 ton. Toch liet dit de groepen nog niet toe om (monetair) 
krediet aan hun leden te verlenen, terwijl anderzijds de bevolking weinig kans krijgt om krediet te verwerven langs officiële weg (cf. het CNCA-verhaal).

Vanuit deze situatie zagen de groepen in dat zij zich op een hoger niveau moesten organiseren en in februari 1991 verenigden een honderdtal groepen die door het project omkaderd werden zich in een Algemene Vergadering en legden zij de grondslag van de CAP (Centrale d'Autopromotion Paysanne), een overkoepelende organisatie die alle spaargroepen die op dat moment bestonden verenigde en die zich als een lokale boerenvereniging (en na verloop van tijd, als bank) begon te profileren.

Deze koepel beheert veel meer middelen dan de individuele groepen, wat hem toelaat om kredieten te verlenen aan haar leden. De CAP richtte ook al vlug een zelfbeheerde winkel van productiefactoren op. Tabel 4 toont enkele kenmerken van de CAP.

\subsection{Bestuur en werking van de spaargroepen en de Centrale d'Autopromotion Paysanne (CAP)}

Elke spaargroep heeft een verkozen beheersorgaan, een zogenaamd comité. Het bestaat uit een voorzitter (meestal de oprichter van de groep, die de belangrijke beslissingen neemt), een secretaris, een penningmeester en een persoon die o.a. de groep vertegenwoordigt in de algemene vergadering van de CAP.

De mannengroepen hadden reeds van in het begin een boekhouding (waarin zij schriftelijk de rekeningen, bijdragen en geleverde arbeid bijhielden), terwijl dit bij de vrouwengroepen niet het geval was omwille van het laag alfabetiseringsniveau van de vrouwen in de streek $(<5 \%$ van de vrouwen kunnen lezen en/of schrijven).

In 1994 was $63 \%$ van alle groepen aangesloten bij de CAP (zie tabel 4).

De verschillende taken van de CAP zijn:

- monetair krediet toekennen aan groepen op basis van kleine bankdossiers en de terugbetalingen innen volgens welbepaalde criteria (elke spaargroep krijgt een carnet d'épargne et de crédit, waarin hij alle verrichtingen bijhoudt);

- de liquide spaargelden centraliseren in bankdepots: CAP heeft een eigen rekening bij de Union Togolaise de Banque (UTB), waarop ze 9\% rente krijgt. Acht percent hiervan vloeit terug naar de groepen; 
- beheren van een centrale winkel voor de verkoop van productiefactoren (zaden, meststoffen,...) en de verhuur van werktuigen;

- innen van omheiningstaksen en beheer van reparaties en/of uitbreiding van groentenpercelen (bij deze groepen die via VE hebben kunnen genieten van steun en begeleiding rond irrigatie en kleinschalige groententeelt).

Het werkingsgeld van CAP bestaat uit een fonds van VE/RAFIA en inkomsten uit het beheer van de spaargelden van de groepen met hun intresten.

\subsubsection{Begunstigden van het project Epargne et Crédit}

De directe begunstigden van het spaar- en kredietprogramma zijn de leden van de groepen en hun familie (ongeveer 4.300 in '93). Dit heeft dus een aantal gevolgen voor een groot deel van de bevolking van de projectstreek (naar schatting 48.000 mensen). De landbouwers (mannen en vrouwen) beslissen zelf of ze deelnemen aan het project. Elke nieuwe en bestaande groep kan een beroep doen op het project en het spaar- en kredietsysteem, en begeleid worden: er zijn immers geen specifieke selectiecriteria.

\subsubsection{Begunstigden van de CAP (tabel 4)}

In 1993 was ongeveer $38 \%$ van alle groepen (evenveel mannen- als vrouwengroepen) geïnteresseerd om een krediet aan te gaan bij de CAP. Dit kwam neer op $60 \%$ van de groepen die lid waren van CAP.

De aansluitingskosten bij CAP voor de groepen bedragen 2.500 fCFA; $63 \%$ van de groepen in de projectzone is aangesloten bij de CAP.

In 1993 konden zo'n 2.000 mensen verdeeld over 80 groepen (enkel lid-groepen) genieten van het krediet dat door de CAP werd verstrekt: dit aantal is beperkt als gevolg van het beperkte werkingskapitaal en de gehanteerde selectiecriteria:

(1) de groep moet een positieve spaarevolutie hebben over de laatste 2 à 3 jaar; dit wil zeggen dat het gespaarde bedrag per lid, en dus het totaal, jaar na jaar toeneemt;

(2) de groep moet een reglementair en gezond intern beheer hebben; en 
(3) de groep moet een minimum bedrag gespaard hebben in natura en/of in speciën met een (tegen)waarde van 35.000 fCFA voor de mannen, en 20.000 fCFA voor de vrouwen.

Het kredietbedrag dat toegewezen wordt, wordt elk jaar door CAP zelf bepaald en bedraagt tot 2 maal de waarde van het door de desbetreffende groep gespaarde bedrag voor mannen en tot 3 maal voor vrouwen. Dit laatste verschil is ingegeven door de constatering dat vrouwen doorgaans gemakkelijker en stipter de aangegane kredieten terugbetalen en dus kredietwaardiger zijn (en in ieder geval een minder groot risico op wanbetaling vormen voor degene die het krediet verleent).

In absolute bedragen uitgedrukt, kan men het eerste jaar een beroep doen op maximaal 100.000 fCFA. Dit maximum bedrag wordt elk jaar herzien en komt overeen met het jaarlijks inkomen van een boerenfamilie. Het toegekende bedrag is het maximum voor de volledige groep.

Het krediet wordt verleend aan een interest op jaarbasis van $15 \%$, waarvan $4 \%$ teruggegeven wordt aan de groep wanneer de terugbetaling regelmatig gebeurd is. Soms wordt geopperd dat deze interestvoet te hoog is (vergelijk met de officiële rentevoeten).

In een eerste fase worden de kredieten op korte termijn toegekend (12 maanden), terug te betalen in twee schijven. Laattijdige terugbetalingen worden bestraft met een maandelijkse gecumuleerde intrestvoet:

$\begin{array}{cc}\text { na } 12 \text { maanden } & 11 \% \\ 13 & 15,19 \% \\ 24 & 17,60 \% .\end{array}$

Geen enkel nieuw krediet wordt toegekend alvorens de terugbetaling van het aan de gang zijnde krediet volledig is afgehandeld. In 1992 werden de eerste kredieten volledig terugbetaald (tabel 4). De terugbetaling van de tweede schijf werd vertraagd door de politieke en economische crisis die Togo in 1993 teisterde. De boeren konden hun katoen en karité (Vitellaria paradoxa; shea nut tree) immers niet verkocht krijgen. Zeventien van de 71 groepen konden ondanks die crisis toch alles terugbetalen in 1992 . In 1993 was $98,7 \%$ van de totale kredieten van ' 92 terugbetaald. 


\subsection{Besteding van het krediet}

Het krediet van CAP kan naar eigen goeddunken van de groep besteed worden. Meestal betreft het een individueel project van één van de leden. Elk lid is dan verantwoordelijk voor de terugbetaling aan de groep van het deel dat hij zelf gekregen heeft, maar toch is het heel de groep die terugbetaalt aan CAP, of tenminste verantwoordelijk is voor de terugbetaling (vermits het de groep is die het contract afsluit met de CAP). Wanneer één lid niet terugbetaalt, wordt bij een volgende vraagronde geen krediet meer verstrekt aan de groep. Dit versterkt de verantwoordelijkheidszin van de leden en bevordert de groepssolidariteit. In de mannengroepen gaat het krediet voornamelijk naar de aankoop van noodzakelijke landbouwinputs, bij de vrouwengroepen naar de financiering van kleine handelsactiviteiten.

Zoals vroeger al aangegeven, kan de groep ook zelf kredieten verstrekken op basis van zijn eigen middelen, hoewel dit nog weinig gedaan wordt. De ervaring leert dat die kredieten voornamelijk bedoeld zijn om medische kosten te dekken (=consumptieve uitgaven).

\subsection{Technische bijstand}

Bij het begin van het programma organiseerde VE vormingssessies over de werking en het beheer van gemeenschappelijke voorraadschuren in de verschillende dorpen. Ook werden de leden van de comités van de groepen opgeleid in beheerstechnieken. In 1992 werd de vorming voor de groepen verzorgd door de Cellule d'Organisation Sociale (CSO), een onderdeel binnenin RAFIA. De secretarissen van de groepen kregen een specifieke opleiding gericht op boekhouding en algemeen secretariaatswerk.

De omkadering van de basisgroepen zelf gebeurde en gebeurt nog door animatoren van het project en bestaat uit sensibiliseringssessies, vorming en begeleiding van zelf-evaluatie.

Het centraal magazijn van CAP heeft in 1992 omkadering gekregen van de AGP (Cellule d'Appui à la Gestion et à la Promotion; cel binnenin RAFIA, die helpt zoeken naar (start)kapitaal voor jonge ondernemers in de informele sector, en hen vorming geeft en beheerstechnieken aanleert). AGP volgt het beheer van het centraal magazijn op.

Het vormingsaspect is heel belangrijk in een project dat steunt op een participatieve aanpak (vertrekkend van de ervaringen van bestaande groepen, het 
ritme van elke groep respecterend,...). Dit is echter slechts mogelijk in een multisectorieel programma van zelfontwikkeling, waar vertrouwen heerst in de ondersteunende en begeleidende organisatie.

\subsection{Resultaten}

De ervaring van de eerste jaren van het spaarprogramma toonde al de geestdrift van de deelnemende landbouwers en landbouwsters. In plaats van onverantwoord hoge interestvoeten van tot $330 \%$ per jaar te moeten betalen aan de handelaars, konden ze het probleem van de overgangsperiode met eigen middelen oplossen.

Door in de groep leningen af te sluiten aan een lagere interestvoet dan bij de privé-handelaars, 'sparen' de landbouwers een intrestvoet van $330 \%$ (verminderd met de interestvoet die binnen de groep geldt) uit, en wanneer het systeem de dekking van de behoeften overstijgt, 'winnen' ze een intrestvoet van $100 \%$ of meer door hun overschotten te verkopen op de markt. Men speculeert hierbij op het prijsverschil op het moment van de verkoopperiode - hoge eenheidsprijzen voor voedsel - en deze bij de oogst, wanneer lage prijzen aansluiten op het verhoogde aanbod. De herinvestering van dit inkomen in hun bedrijf en/of andere productieve activiteiten maakt het mogelijk een autonome en financieel solide basis van economische ontwikkeling op te bouwen.

De organisatie van de spaargroepen in een CAP-structuur ${ }^{4}$ was zeer belangrijk voor het door VE geïnitieerde programma, en was het resultaat van drie jaar sensibilisering en vorming in het beheer van collectieve spaarbedragen.

Ondanks de beperkingen qua aantal en bedrag (= de ontleende bedragen blijven doorgaans beperkt), geeft de kredietverlening toch hoopgevende resultaten: vanaf de oprichting van de CAP draaide het magazijn onmiddellijk goed, want het krediet werd/wordt gebruikt voor de aankoop van productiefactoren.

Het effect van de stakingen van 1993 op het spaargedrag was niet groot (de projectzone lag ver van de streek, met name het zuiden en de regio rond Lomé, die vooral door de stakingen getroffen werd). Wel is het zo dat veel boeren in het

\footnotetext{
${ }^{4}$ Naar idee en uitwisseling is de CAP te beschouwen als een Boerenbond naar VlaamsBelgisch model. De CAP (1) groepeert informele boerengroepen; (2) verstrekt kredieten op basis van (3) financiële middelen die de groepen-leden bij elkaar sparen; en (4) staat in voor een zekere dienstverlening; de organisatie laat toe dat (5) een grote groep boeren gemeenschappelijk, als één (rechts)persoon, naar buiten toe kan optreden en zodoende de belangen van de individuele boeren via hun informele groepen kan verdedigen en/of betere prijzen kan bedingen voor aan- en verkochte producten.
} 
land door de staking niet meer aan voldoende meststoffen (staatsmonopolie voor de verdeling) konden geraken. De boeren uit de projectstreek hadden in dat opzicht veel meer zekerheid omdat zij gezamelijk via CAP konden aankopen en op die manier toch nog toegang hadden tot meststoffen bij de staat. Bovendien heeft de CAP op een bepaald moment zelf het initiatief genomen om meststoffen van uit de haven te Lomé op te kopen en naar het CAP-gebied te brengen op een moment dat niemand in het land aan meststoffen kon komen.

\subsection{Nieuwe initiatieven}

In het noordwesten van de regio (Nadjoundi), waar sedert kort meer dan 50 groepen operationeel zijn, is recentelijk een nieuwe CAP gevormd. Een derde CAP is in voorbereiding in het oosten (Papri). Een nieuw dossier ingediend door RAFIA/VE met de vraag om het project verder te zetten en uit te breiden is recentelijk goedgekeurd voor cofinanciering bij de Europese Unie.

Verder wordt onderzocht of er andere beleggingsvormen mogelijk zijn om het spaargeld beter te laten renderen, en of er een band mogelijk is met het formele bank- en/of kredietcircuit. Tot op heden bestaat er geen formele band noch akkoord tussen de rurale "bank" CAP en de officiële banken, afgezien van de officiële rekening die CAP heeft bij de commerciële bank UTB, met succursaal te Dapaong (die echter helemaal niet geinteresseerd is in kredietverlening op het platteland).

\subsection{Gelijkaardige interventies in de projectzone}

3.10.1. Maisons Familiales is een NGO uit de jaren ' 60 die aan landbouwvorming doet van jongeren die in groep begeleid worden en die vooral productieve landbouwactiviteiten ontplooien.

3.10.2. JARC (Jeunesse Agricole Rurale Chrétienne) begeleidt ook groepen die sparen in natura volgens hetzelfde principe. Hier moeten ze echter, vooraleer ze krediet krijgen, binnen de drie jaar 2 ton graan gespaard hebben. $\mathrm{Nu}$ begeleiden zij 29 groepen van gemiddeld 13 leden. In 1994 plannen zij om er 30 groepen bij te nemen, hoewel ze 90 aanvragen kregen, maar hun middelen zijn beperkt. 
3.10.3. EDF (European Development Fund) is werkzaam met een gelijkaardige filosofie als die van de CAP's in de streek ten westen van de projectzone van RAFIA.

3.10.4. FIDA (Fonds International pour le Développement Agricole) volgt ook dezelfde filisofie, en werkt met heel veel geldelijke en menselijke middelen. Een project dat een gelijkaardige aanpak ambieert als die van Vredeseilanden/RAFIA (en mede voorbereid werd door één van de auteurs van dit artikel) is begin april 1994 van start gegaan in een streek ten zuiden van het Vredeseilanden/RAFIA-project.

Beide vorige organisaties leggen echter (te) weinig of geen nadruk op de eerste stap in het kredietverstrekkingsproces, $\mathrm{nl}$. het sparen in natura. Bovendien vragen/verwachten zij veel te vlug "tastbare" resultaten, terwijl een traag opbouwritme juist één van de voorwaarden lijkt te zijn om de spaar- en kredietactiviteiten van de informele groepen een kans op slagen te geven.

3.10.5. Voor de streek ten zuiden van de projectzone is er een akkoord van VE/RAFIA met PNUD, waar men zou werken met vrouwengroepen rond o.a. gezondheidszorg.

\section{DE LOI-CADRE, EEN BEDREIGING VOOR DE CAP- STRUCTUUR}

In mei ' 93 werd door de BCEAO een voorstel gedaan voor een kaderwet met betrekking tot spaar- en kredietinstellingen. Dit ter aanvulling van de bestaande bankwet (daterend van 1906!), waarin nog niets vermeld stond over informele noch rurale financiële organisaties.

Het Projet d'Appui à la Réglementation sur les Mutuelles d'Epargne et de Credit (PARMEC/UMOA) formuleerde de probleemstelling als volgt:

(1) de moeilijkheid om toegang te krijgen tot traditionele financieringsbronnen voor gezinnen, de landbouw, veeteelt en visvangst, KMO's;

(2) het gebrek aan een aangepaste reglementering voor de bevordering van spaar- en kredietfondsen. 
Als oplossing stelden zij voor een spaar- en kredietfonds op te richten in de landen van de UMOA, daarvoor een gemeenschappelijke reglementering op te stellen, en een aangepast controlemechanisme op poten te zetten. Het projectvoorstel dat zij hiertoe uitgewerkt hadden, kreeg als titel mee Réglementation des Institutions Financières Mutualistes ou Coopératives d'Epargne et de Crédit.

De voorstanders van deze reglementering (vooral economisten, juristen en financierders) haalden vooral aan dat een juridisch kader bescherming tegen misbruiken kan bieden voor de vaak nog zwakke (spaar- en krediet)groepen van diverse pluimage die her en der in de BCEAO-lidlanden zijn ontstaan doorheen de jaren, en voor de bevolking. FUCEC- dat zich profileert als het (enige) aangewezen instituut in Togo om zich met (landbouw)krediet bezig te houden, zou naar aanleiding van dit voorstel, zijn positie als NGO en 'basisorganisatie' kunnen verstevigen.

In kringen van andere (echte? $\left.{ }^{5}\right)$ basisorganisaties, NGO's en kleine coöperatieven en pre-coöperatieven (zoals bv. CAP) stond men echter zeer sceptisch tegenover dit voorstel (hierin gesteund door de vertegenwoordiger van FAO in Togo). Veel van deze organisaties stellen immers niet alleen sparen en krediet centraal, maar gebruiken deze benadering ook als middel dat kadert in een integrale ontwikkelingspolitiek. Het zijn dus geen financierings-organisaties maar ontwikkelingsorganisaties.

Enkele van hun kritieken waren:

- de onduidelijkheid met betrekking tot de précoopératives, en clubs d'épargne et de crédit. De plaats van het informele is niet duidelijk gepreciseerd in het wetsvoorstel. Slechts 4 artikels gaan concreet over spaar- en kredietgroepen. De rest van de tekst betreft instellingen die gevormd en gestructureerd zijn volgens de filosofie van de officiële bankinstellingen;

- het is moeilijk tot contraproductief om een instelling die de wetmatigheden van het internationale banksysteem volgt (in casu de BCEAO), te willen doen samengaan met een instelling van coöperatieve aard. Het risico tot miskenning van de spaarkassen door de bevolking wordt aldus groot;

- de voorziene kaderwet werkt zeer centraliserend en er is geen enkele rol toebedeeld aan het regionaal en lokaal niveau; het Togolese ministerie dat verantwoordelijke is voor de opvolging van dit dossier is dat van financiën en niet dat van rurale ontwikkeling. Dit toont duidelijk aan dat hier enkel het

\footnotetext{
${ }^{5}$ Met "echte" bedoelen we hier organisaties die vanuit de basis ontstaan zijn en ook door die basis geleid worden.
} 
financiële aspect een rol speelt, terwijl de ontwikkelingsdimensie totaal buiten beschouwing blijft;

- het proces van institutionalisering dat geviseerd wordt door deze wet, beperkt zich enkel tot de reglementering, zonder de economische en sociale aspecten te integreren, en rekening te houden met de verscheidenheid van ervaringen in en tussen verschillende landen. Het document is immers identiek voor alle landen en terzelfdertijd toch heel detaillistisch, zodat er praktisch geen ruimte is voor ieder land apart om rekening te houden met zijn eigen specifieke situatie.

Uit dit alles blijkt dus duidelijk dat de realiteit helemaal anders is dan wordt voorgesteld: de UMOA heeft PARMEC enkel gelanceerd omwille van het falen van de banken in de begeleiding van de ontwikkeling van de zone; het voorstel komt alleen ten goede aan de BCEAO. Ook Canada heeft bij het ganse wordingsproces rond de BCEAO een bedenkelijke rol gespeeld met haar hulp aan de BCEAO en nu ook aan het BIT (Bureau International de Travail).

Het feit dat meer dan de helft van de banksector in de fCFA-zone failliet is, mede door de enorme kapitaalvlucht uit de zone door o.a. aantrekkelijke beleggingsmogelijkheden in het buitenland, en dat daarnaast de coöperatieve beweging een sterke groei gekend heeft (vooral in Togo en Kameroen) en bedragen beheert in de orde van miljarden fCFA, en dus niet verwaarloosbaar is op de financiële markten, heeft de centrale banken ertoe aangezet hier de hand te willen op leggen.

Dit project zou - bij een eenzijdige oplegging - de ervaringen en al bestaande interventies in Afrika op gebied van sparen en krediet op het informele platteland ruïneren. Een dergelijke rigide (over)reglementering kan niet van toepassing zijn op lokale basisinstellingen met een culturele identiteit die de leden bindt, en die de tijd moeten krijgen om uit te groeien tot goed gestructureerde organisaties en moeten kunnen evolueren zoals zij het zelf wenselijk achten. Elk formalisme van overheidswege zou hier in principe nieuwe initiatieven tegenwerken, en zou nauwelijks nog ademruimte laten voor een structuur zoals CAP. Bovendien is het moeilijk voor zulke instellingen om dergelijke regels correct te interpreteren, toe te passen en te controleren.

Het is belangrijk dat zij 'erkend' worden en dus beschermd zijn, maar hiervoor is een soepele structuur nodig. Het is beter de bevolking zelf naar eigen oplossingen te laten zoeken voor haar vraag naar krediet, zonder haar onmiddellijk in een formeel, juridisch en financieel kader te willen vastzetten (kijk naar de mislukking van de CNCA in het verleden, die een 'perfect' wettelijk kader had, maar toch failliet is gegaan). 
De wet is uiteindelijk toch goedgekeurd in december '93, mits enige aanpassingen: zo is het artikel over de précoopératives et clubs d'épargne et de crédit eruit gelaten. De CAP valt dus voorlopig niet onder deze wet. Voor dergelijke informele instellingen is een speciaal protocol in overleg met de minister van financiën in de maak. Afwachten wat dit wordt...

De 'echte' coöperatieven zijn echter wel de dupe van de nieuwe wet: COOPEC's (Coopératives d'Epargne et de Crédit) zijn de belangrijkste kredietverleners op het platteland sinds het verdwijnen van de CNCA. Net zoals de CAP waren ook zij nog niet gereglementeerd en beschermd door een wet in Togo.

Er is dus wel degelijk nood aan de bescherming van deze laatste vorm van coöperatieven, maar dit kan wellicht het best gebeuren middels een specifieke, nieuwe wet. COOPEC's hebben een ander systeem dan dat van de banken en willen niet aan hetzelfde regime onderworpen worden. De verantwoordelijken van de coöperatieven vrezen immers dat de banken en de regering enkel aanspraak willen maken op deze instellingen en vooral op hun bezittingen (de centrale kassen moeten echter hun reserves kunnen behouden tot op het moment waarop er meer vraag naar geld is), en dat zij geen begrip zullen opbrengen voor de principes van waaruit hun succes gegroeid is.

Daarom ware het beter geweest dat de BCEAO op internationaal vlak zou samenwerken met de internationale beweging van coöperatieven (WOCCUACCOSCA), omdat dit de enige manier is om het belang van alle partijen te verdedigen. Spijtig genoeg is gebleken dat zelfs deze beweging op cruciale momenten haar verantwoordelijkheid niet voldoende neemt: tijdens de onderhandelingen ter voorbereiding van de PARMEC-wet in Dakar legde zij een vernietigend rapport voor over deze wet, en achter de schermen leverde zij zware negatieve kritiek, terwijl zij zich op de beslissende vergadering (in aanwezigheid van de ministers) niet meer heeft laten horen.

\section{IMPACT VAN HET VE/RAFIA-PROJECT OP DE LOKALE VOEDSEL-VEILIGHEID}

Zoals hierboven al aangehaald zijn er in het noorden van Togo in jaren van normale weersomstandigheden graanoverschotten die echter moeilijk kunnen bewaard worden en vaak verkwist worden na de oogst. Dit terwijl de graanprijs tijdens het droogseizoen verdubbelt en er bij een slechte oogst graan moet 
geleend worden bij handelaars tegen rentes die oplopen tot $330 \%$ op jaarbasis. Ook voor de aankoop van inputs moet, gezien het lage inkomen van de boer, geld geleend worden aan hoge intresten.

Door het sparen in groep van (zelfs kleine hoeveelheden) graan tot de droge periode kan graan ontleend worden binnen die groep aan lage intresten zodat de beschikbaarheid van voedsel toeneemt voor de boer (en zijn familie) die tekorten heeft. De toegang tot voedsel neemt toe voor de boer die overschotten spaart wegens een stijging in zijn inkomen. Vermits dit spaarsysteem georganiseerd is in kleine groepen, zijn kredietverlening en sparen nauw aan elkaar gekoppeld. Indien de leden van een groep kredieten hebben aangegaan, zullen ze die correct afbetalen en als ze overschotten hebben, zullen ze die sparen omdat ze afhankelijk zijn van de stocks om nieuwe kredieten te kunnen verkrijgen. Gezien het kleinschalige karakter van de spaargroepen, is een formeel (juridisch) kader niet echt nodig om misbruiken te vermijden. Ieder lid van de groep kent ieder ander lid en dit is een voldoende garantie voor interne controle. Niettegenstaande deze cohesie worden er wel duidelijke sociale regels opgesteld.

Globaal gezien maken deze stocks slechts 4 tot $5 \%$ uit van de totale oogst van de spaargroepen (wat al evenveel is als wat TOGOGRAIN, de voormalige staatsdienst die graanoverschotten opkocht en op cruciale momenten verdeelde, op nationaal vlak beheerde toen deze dienst op z'n best functioneerde) maar ze nemen nog steeds toe. Ze zijn zeker niet voldoende om de vraag naar voedsel te dekken in geval van een algemene mislukking van de oogst, maar ze vormen toch een belangrijke lokale buffer die de zelfvoorzieningsgraad van de boeren en bijgevolg ook hun voedselveiligheid verhoogt.

Bovendien komt er door het sparen in natura extra geld vrij dat gebruikt kan worden voor lokale ontwikkelingsdoeleinden (o.a. aanleg/onderhoud van wegeninfrastructuur, medische zorgen) en waarvan een deel op zijn beurt kan gespaard worden, zodat ook een geldelijke reserve ontstaat (beheerd door de CAP) die kan dienen voor kredieten voor landbouwinputs of commercialisatie van landbouwproducten.

Zo kadert het spaar- en kredietproject in een bredere context van autonome rurale ontwikkeling, wat de boer in Togo zeker nodig heeft gezien hij enkel voor exportgewassen kan rekenen op 'steun' van de overheid (krediet, inputs,...). Dit overheidsbeleid stuurt echter aan op de teelt van exportgewassen in plaats van voedingsgewassen, wat de voedselzekerheid niet (rechtstreeks) ten goede komt. Op nationaal niveau bleek onlangs (in 1992) duidelijk dat internationale handel als buffer tussen vraag en aanbod van voedsel in plaats van zelfvoorziening en stockage zeker niet veilig is om op terug te vallen (toen de ruilverhoudingen 
instortten, werd voedselimport plotseling dubbel zo duur). Op de korte termijn stijgt ook de reële waarde van de exportgewassen wel, maar omwille van internationale marktmechanismen zal deze snel weer zakken, wat trouwens beoogd werd met de devaluatie van de fCFA in januari 1994.

Hoewel ook de productiefactoren (zoals meststoffen en pesticiden), die noodzakelijk zijn voor en moeten aangewend worden in de exportteelten, veel duurder geworden zijn, heeft de devaluatie in zekere zin wel effect gehad op de keuze die de boer maakt, namelijk produceren voor voedsel of voor de export. Het effect van de devaluatie op de voedselprijzen treft vooral importgoederen voor stedelijke consumptie en zal dus op het platteland niet zo sterk gevoeld worden.

Zeker nu geïmporteerd voedsel zoveel duurder wordt, zou voedselhulp moeten gericht zijn op driehoekstransacties, in plaats van de transfer van tarwebloem en rijst vanuit het Westen naar het zuiden. Hoewel deze voedselhulp slechts ongeveer een tiende van de graanimport uitmaakt, bestendigt die de veranderde voedingsgewoonten in de steden. Bovendien heeft het sparen in natura voor de boeren van Noord-Togo enkel waarde als er ook een lokale markt is voor door hen geproduceerd en gestockeerd graan. Vermits de gehele regio normaal een surplus produceert, moeten deze overschotten kunnen afgezet worden op plaatsen met tekorten. Indien het westen wil investeren in duurzame ontwikkeling van het zuiden, kan het beter terecht op de graanmarkt in Noord-Togo om voedselhulppakketten samen te stellen, dan in de V.S. of in Europa. De voedselzekerheid van zowel de boeren van Noord-Togo als Togo zelf zou hiermee sterk vooruit gaan.

De Europese Unie blijkt echter slechts voor 5\% van haar voedselhulp ook na te denken over de effecten die die hulp heeft: in 1990 werd slechts $1 / 20$ e van alle Europese hulpgraan opgekocht in de ontwikkelingslanden zelf om het te gebruiken voor driehoekstransacties.

\section{BESLUIT}

De Togolese economie is meer en meer afhankelijk van de export van basisproducten. Hun prijs op de wereldmarkt is echter zeer wisselvallig en toont voor de landbouwproducten een dalende trend. Terwijl de waarde van de fCFA ten opzichte van vreemde valuta relatief stabiel bleef en globaal over de laatste jaren zelfs steeg, verloor de fCFA onlangs na de devaluatie (januari 1994) abrupt de helft van haar waarde, wat een verdere daling van de exportprijzen mogelijk maakte. Buiten de onzekerheid op de internationale markt bleek in 1993 dat ook 
op nationaal niveau de minimumprijzen en de opkoop van exportgewassen helemaal niet verzekerd zijn.

Eén van de redenen waarom die export zo belangrijk is, is de steeds aangroeiende schuldenlast, die met de devaluatie van de munt plotseling dubbel zo zwaar weegt. Wat echter nog zwaarder begint te wegen op de economie is het betalingsbalanstekort, dat ook nog sterk zal stijgen als gevolg van de devaluatie.

Deze devaluatie kadert in de hele politiek van structurele aanpassingen en neoliberaal denken, die door de Wereldbank en het Internationaal Muntfonds gepromoot worden. Bij deze aanpak zijn alle mogelijke lokale interventiemaatregelen volkomen uit den boze en is enkel de versteviging van de economische slagkracht van belang. De grote verliezer van een dergelijke economische wereldoorlog is uiteraard de gewone Togolees. De kleine boer ziet zijn inkomen steeds maar slinken, de straatventer moet belastingen betalen op een inkomen waarvan hij amper kan leven en de staatsfunctionaris mag blij zijn dat hij nog niet ontslagen is.

Ook de meeste hulp aan Togo vaart onder hetzelfde vaandel en wordt afhankelijk gemaakt van het toepassen van structurele aanpassingsprogramma's (SAP's) en is vooral gericht op stedelijke ontwikkeling, de haven, exportindustrieën, kortom zowat alles wat er nodig is om de betalingsbalans onder nul te houden en export van basisproducten te verzekeren. Ook voedselhulp is hoofdzakelijk gericht op stedelijke consumptie. De kleinere hoeveelheid financiële hulp die naar rurale ontwikkeling gaat, wordt als sociale correctie voorgesteld.

De oorzaken van de voedselonveiligheid liggen niet zozeer in het lage gebruik van inputs of in de lage rendementen van de traditionele landbouw, maar wel in het gebrek aan diversifiëring (vooral naar voedselgewassen voor de eigen consumptie), onvoldoende stockeringsmogelijkheden, veranderde stedelijke consumptie en lage inkomens.

In de wurggreep van schuldeisers en geldschieters ziet de Togolese overheid zich verplicht exportgewassen te promoten en de grenzen open te stellen ten koste van basisontwikkeling en voedselveiligheid. Zo zijn staatsinterventies voor stockage van granen en landbouwkrediet onderuit gegaan en wordt plattelandsontwikkeling enkel nog gezien als een sociale correctie van de structurele aanpassingen, die bovendien a priori wordt overgelaten aan NGO's.

Anderzijds worden grond en arbeid die broodnodig zijn voor de productie van basisvoedsel en diversificatie (d.m.v. groentetuinen) geconcentreerd op de katoenteelt. Ook de inkomens van de boeren die naast hun gierst katoen telen, zijn dikwijls op de helling gebracht omwille van de afbrokkelende 
wereldmarktprijs van katoen, het uitblijven van een nationale opkooppolitiek of de verhoogde kredietlast voor de aankoop van de inputs.

Het spaar- en kredietproject van RAFIA/VE in Noord-Togo is niet geconcipieerd als een sociale correctie, maar beoogt een geïntegreerde autonome ontwikkeling van het platteland. Naast de stockage van basisvoedsel en een zelfbeheerd kredietsysteem sluit dit project aan bij een globale aanpak rond erosiecontrole, diversificatie van de voeding, gezondheidszorg, alfabetisering en vorming op organisatorisch vlak.

Deze aanpak zou internationaal moeten gesteund worden door de hulp af te buigen van importbestendiging naar duurzame ontwikkeling; door hulpgraan op te kopen bij de boeren in Noord-Togo wanneer er tekorten zijn, en het triangulair te verspreiden, en door eerlijke handel met Togo voorrang te geven op economische oorlogvoering. 


\section{Referentielitteratuur}

BARNABO, F., COUNET, M., DJORE, L., JANSSENS, M., VAN DAMME, P. (1993). Emergence d'une organisation d'épargne et de crédit au Nord-Togo. Echos du Cota, (1), 3-10.

BARNABO, F., COUNET, M., DJORE, L., JANSSENS, M., VAN DAMME, P. (1993) Une organisation d'épargne et de crédit au Nord-Togo. Bulletin d'information du réseau GAO (Groupements - Associations villageaoises - Organisations paysannes), 15, 6-9.

BERTHOD, P., VAN DAMME, P., VENOT, F. en VOUILLOT, A. (1995). Projet d'Organisation Villageoise et de Gestion de Terroir (POVGT). Aide-mémoire. Mission de Formulation du 22 Mars au 15 Avril 1995, Lomé, Ministère de développement Rural, de l'Environnement et du Tourisme, $13 \mathrm{pp}$.

COUNET, M., DE GROOTE, H., DE SCHRYVER, A. en VAN DAMME, P. (1985). Voorstudie voor een vredeseiland in Dapaong, Noord-Togo. Vredeseilanden, Ruelensvest 127, 3001 Leuven, 344 pp., + 127 pp. bijlagen.

COUNET, M., DE GROOTE, H., DE SCHRYVER, A., en VAN DAMME, P. (1986). Préétude pour une ILE DE PAIX à Dapaong (Nord Togo). Vredeseilanden, Ruelensvest 127, 3001 Leuven, $388 \mathrm{pp}$.

COUNET, M. en VAN DAMME, P. (1987). Méthodes d'identification et de suivi d'un projet de développement intégré: de la théorie à la pratique. Mededeling op het 'VII Seminaire d'économie et de sociologie rurales', georganizeerd door C.I.R.A.D.M.E.S.R.U., Montpellier, 14 - 18 September 1987, $20 \mathrm{pp}$.

COUNET, M. en VAN DAMME, P (1989). Méthodes d'identification et de suivi d'un projet de développement intégré (Dapaong, Nord Togo). Afrika Focus, 5 (1/2), 65-78.

COUNET, M. en VAN DAMME, P. (1990). Méthodes d'identification et de suivi d'un projet de développement intégré: étude de cas au Togo. Tropicultura, 8, 21-25.

COUNET, M., VAN DAMME, P. (1995). Rapport de mission au Bénin et au Togo 25/12/9408/01/95. Vredeseilanden, Ruelensvest 127, 3001 Leuven, 13 pp.

COUNET M., en VAN DAMME P. (1996). "La caisse ne risque pas d'être rentable" (sic). Rapport de mission de Myriam Counet et Patrick Van Damme au Sénégal, 26 décembre 1995 - 08 janvier 1996; $20 \mathrm{pp}+6 \mathrm{pp}$ annexes.

VAN DAMME, P. (1987). Review of the Evaluation of the "Opération d'intensification agricole dans la Région des Savanes, Togo" as executed by BMB. Report submitted to F.I.D.A., Via del Serafico, 107, I-00142 Rome, 6 pp. 
VAN DAMME, P. en GABRIEL, K. (1992). Market Situation and Price Setting for Cereals and Vegetables on Three Rural Markets in Northern Togo. Acta Horticulturae, 296, 249-256.

VAN DAMME P. (1992). Emergence d'une organisation populaire d'épargne et de crédit au Nord-Togo. Mededeling gehouden op het seminarie 'Financial Landscapes Reconstructed', georganizeerd door de Landbouw Universiteit Wageningen, 17 November 1992.

VAN DAMME P. (1995). Rapport de retour de mission (BTO) Bénin - Projet d'activités génératrices de revenus (PAGER), International Fund for Agricultural Development (IFAD), Via del Serafico 107, I-00142 Roma (Italia), 5pp + 2 annexes (15+3pp).

VAN DAMME P. (1995). Back-to-office Report (BTO) Benin - Income Generating Activities Project. Appraisal Mission - Round Table on Rural Sector 21-22 September 1995. Rome, International Fund for Agricultural Development (IFAD), Via del Serafico 107, I-00142 Roma (Italia), $3 p p+6$ annexes (49 pp).

VAN DAMME P. (1995). Project brief 'Project d'activités génératrices de revenus (PAGER) ' Income Generating Activities Project). IFAD evaluatie zending, Benin, Ministery of Rural Development, 5pp. 